\title{
SOLICITATION OF CHILDREN FOR SEXUAL PURPOSES: THE NEW OFFENCE IN THE EU (UNDER THE DIRECTIVE 2011/92/EU)
}

\author{
Libor Klimek $^{1}$
}

\section{Faculty of Law, Pan European University, Bratislava, Slovak Republic email: libor.klimek@yahoo.com}

KLIMEK, Libor. Solicitation of Children for Sexual Purposes: The New Offence in the EU (Under the Directive 2011/92/EU). International and Comparative Law Review, 2012, Vol. 12., No. 1, pp. 141-151. DOI: 10.1515/iclr-2016-0083.

\begin{abstract}
The article deals with the rules for a grant of interim measures in the context of EU law and its application in national judicial proceedings. It covers the key case-law of the Court of Justice of the EU related to the regime, conditions and limits of the interim measures and adds a reflection of practice of Czech courts. Article pays particular attention to the conditions for suspension ofn the application of national law measures.
\end{abstract}

Keywords: EU Law, national courts, national procedural rules, interim measures

\section{Introduction}

In March 2010, a 33-year-old registered sex offender was convicted of the rape and murder of a 17-year-old girl. The murderer had used a fake photograph to present himself on Facebook as a handsome young teenager. He met his victim there and befriended her. An online romance developed and he then persuaded her to meet him in real life. On the day of the arranged meeting, he sent the girl a text message saying that his father would pick her up in his car. Of course this was a lie. Her body was found in a field the next day. ${ }^{2}$

We typically teach our children that when someone in a car pulls up and asks them for directions, they should not approach the car. They should run away from the car and tell their parents. We teach them that the person in the car might not really have been asking for directions etc. What they are really saying

1 JUDr. Libor Klimek. Ph.D. student in the filed of Criminal law (specialization: EU Criminal law), Faculty of Law, Pan European University, Bratislava, Slovak Republic. Email: libor.klimek@yahoo.com

2 Retrieved from: CARR, J.: The Internet dimension of sexual violence against children. In: Protecting children from sexual violence: A Comprehensive Approach. Strasbourg : Council of Europe Publishing, 2010, (pp. 271-288), p. 274. 
is 'Are you foolish enough to come close to my car so I can pull you inside?' In the same fashion, we need to teach our children what might really be behind the questions online predators ask. ${ }^{3}$

Rapid growth of the Internet and advances in technology mean enormous benefits to society, and children should be able to enjoy the benefits that the Internet offers safely. However, it is necessary to recognise that with the spread of the Internet comes the growth in the possibility of the system being abused by sex offenders. ${ }^{4}$ The Internet has introduced us to many new terms and phenomena. One which has received considerable attention is that of online grooming. While grooming itself is not new, the Internet and other forms of electronic communication have provided offenders with greatly increased opportunities for contact with children. In these days, internet communication and social networks enable virtually anyone to communicate privately with children directly in their homes. Many cases have involved adult males who have used the Internet to groom a child, preparatory to committing acts of sexual violence against them. ${ }^{5}$

The general policy objective of the EU is to ensure a high level of security through measures to prevent and combat crime, which includes child sexual abuse and child sexual exploitation. It should be done primarily by establishing minimum rules concerning the definition of criminal offences and sanctions in the area of sexual exploitation of children. ${ }^{6}$

A number of European states have already made online grooming an offence through domestic legislative measures. However, in these days the Member States of the EU are faced with the new task of implementing the 'double European obligation'7 to make grooming a criminal offence - 'solicitation of children for sexual purposes' - at the national level. On the one hand, in 2007 the Council of Europe (all Member States of the EU are members of the Council of Europe) adopted the Convention on the Protection of Children against Sexual Exploitation and Sexual Abuse. ${ }^{8}$ On the other hand, in 2011 the EU adopted the

3 SUlliVAN, M.: Online Predators : A Parent's Guide for the Virtual Playground. Maitland : Xulon Press, 2008, pp. 133-134.

4 DAVIDSON, J. et GOTTSCHALK, P: Internet Child Abuse: Current Research and Policy. Abingdon - New York : Routlegde, 2011, p. 92.

5 See CARR, J.: The Internet dimension of sexual violence against children. In: Protecting children from sexual violence: A Comprehensive Approach. Strasbourg : Council of Europe Publishing, 2010, (pp. 271-288), p. 273.

6 Articles 67 and 83 of the Treaty on the Functioning of the EU (as amended by the Treaty of Lisbon). OJ, C 83/47 of 30.3.2010.

7 KOOL, R.: Prevention by All Means? : A Legal Comparison of the Criminalization of Online Grooming and its Enforcement. In: Utrecht Law Review, Vol. 7 (2011), Issue 3 (pp. 46-69), p. 47.

8 Council of Europe, European Treaty Series n ${ }^{\circ} 201$ (2007). The Convention was opened for signature in Lanzarote (Spain), on 25 October 2007. 
Directive 2011/92/EU on combating the sexual abuse and sexual exploitation of children and child pornography. ${ }^{9}$

This paper deals with the offence of 'solicitation of children for sexual purposes' at the EU level, i.e. in the light of the newly adopted Directive 2011/92/EU on combating the sexual abuse and sexual exploitation of children and child pornography. The principal aim of this paper is to examine the context of criminalizing behaviour related to child sexual 'online' grooming in the EU. It is divided into main three sections. First introduces a general overview of online grooming and gives examples. Second section deals with child sexual grooming in individual States, while third section, which represents a key aspect of the paper, deals with the offence of solicitation of children for sexual purposes.

\section{Online Grooming: A General Overview}

Grooming is a well-known strategy used by many paedophiles. It is a subtle, painstaking and powerfully seductive process, which can take many days, months, or sometimes years, to evolve and prepare the child for sexual abuse. It can allow paedophiles to sexually abuse large numbers of children but remain undetected. ${ }^{10}$

No binding legislation has been adopted in worldwide context. However, the literature offers endless number of definitions. For example, Davidson and Gottschalk argue that grooming is the process by which a person befriends a child with the intention of committing sexual abuse ${ }^{11}$, or Ost argues that grooming can be conceived as a predatory act committed in order to facilitate sexual abuse. $^{12}$

The Internet has a great deal to offer - the opportunity to learn and research any number of subjects or to communicate worldwide with friends or family, to maintain and create business, or plan the next holiday. These are just a few of the thousands of working options available to the user. However, on the other hand, not everyone uses the Internet in a totally moral, ethical and legal fashion.

Online victimisation has been a serious problem for many years. Children and young people are active users of online technologies, and have in many instances more expertise and experience in the use of information technology than their parents, teachers or other adults. However, as a consequence of the

9 Directive 2011/92/EU of the European Parliament and of the Council of 13 December 2011 on combating the sexual abuse and sexual exploitation of children and child pornography, and replacing Council Framework Decision 2004/68/JHA. OJ, L 335/1 of 17.12.2011.

10 SANDERSON, Ch.: Counselling Adult Survivors of Child Sexual Abuse. London : Jessica Kingsley Publishers, 2006, p. 29.

11 DAVIDSON, J. et GOTTSCHALK, P: Internet Child Abuse : Current Research and Policy. Abingdon - New York : Routlegde, 2011, p. 80.

12 OST, S.: Child Pornography and Sexual Grooming : Legal and Societal Responses. Cambridge University Press, 2009, s. 32. 
possibilities that lie within the services offered online, such as social network services, their own behaviour and the behaviour of people with a sexual interest in children in terms of harmful conduct, children and young people are vulnerable and may become victims of sexual abuse. ${ }^{13}$

Sexual grooming on the Internet primarily consists of paedophiles using personal websites to target children who meet the paedophile's specific predilection for age, gender and looks. Grooming may take minutes, hours, days or months, depending on the goals and needs of the abuser and reactions of the young person. Paedophiles target in particular websites that provide public information about the child's profile. The aim is to befriend a child online to sexually abuse offline at a later date. ${ }^{14}$

Social networking sites, such as MySpace.com or Facebook.com, are widely popular among youth and adults alike. Children using the Internet innocently can make contact with anyone, and be contacted by anyone, while online. Abusers who choose to use the facilities of Internet chat rooms are not always who or what they purport to be. They learn the typical online chat terms and phrases, and make childlike or adolescent comments, all in an effort to disguise their true age and gender and to be accepted within the 'child chat-room sect.'.15 the hands of a sexual predator, chat rooms, instant messaging and other Internet applications become tools for grooming victims. ${ }^{16}$ Some groomers have up to 200 young people on their online 'friends' lists who are at different stages of the grooming process at any given time. ${ }^{17}$

In addition to that, $3 \mathrm{G}$ mobile phones with features such as Internet access and cameras can allow children access to Internet sites in which they can be groomed, view child pornographic images, and be encouraged to take pictures of themselves in sexual poses and send them to the paedophiles. Such production and trading in images implicates the child in illegal activities of being both the producer and distributor of child pornography. ${ }^{18}$

13 DAVIDSON, J. et GOTTSCHALK, P: Internet Child Abuse : Current Research and Policy. Abingdon - New York : Routlegde, 2011, p. 79.

14 SANDERSON, Ch.: The Seduction of Children : Empowering Parents and Teachers to Protect Children from Child Sexual Abuse. London - Philadelphia : Jessica Kingsley Publishers, 2004, p. 153.

15 POWELL, A.: Paedophiles, Child Abuse and the Internet : A Practical Guide to Identification, Action and Prevention. Oxon : Radcliffe Publishing, 2007, pp. 116-117.

16 DEAN, S.: Sexual Predators: How to Recognize Them on the Internet and on the Street: How to Keep Your Kids Away. Los Angeles - Aberdeen : Silver Lake Publishing, 2007, p. 73.

17 WEBSTER, S. - DAVIDSON, J. - BIFULCO, A. - GOTTSCHALK, P. - CARETTI, V. PHAM, T. et GROVE-HILLS, J.: Scoping Report of the European Online Grooming Project. Prepared for and co-funded by the European Commission Safer Internet Plus Programme, 2010, p. 13.

18 SANDERSON, Ch.: The Seduction of Children : Empowering Parents and Teachers to Protect Children from Child Sexual Abuse. London - Philadelphia : Jessica Kingsley Publishers, 2004, p. 154. 
On the one hand, the children most at risk of being groomed are usually between the ages of ten and sixteen. This can be explained by the fact that younger children do not, or at least less often, communicate through the Internet. Furthermore, girls have a higher risk of being groomed than boys, but boys also form a substantial group of victims. ${ }^{19}$

On the other hand, the perpetrators of child sexual abuse come from various demographic, economic and social backgrounds. It was shown that some sexual offenders were individuals in respectable professions such as lawyers and teachers. ${ }^{20}$ An online groomer can be defined as someone who has initiated online contact with a child with the intention of establishing a sexual relationship involving cyber-sex or sex with physical contact. ${ }^{21}$

\section{Criminalizing Child Sexual Grooming in Individual States}

In European states, the number of existing offences can apply to behaviour related to sexual exploitation of children or child pornography. Despite this fact, it is only relatively recently that the laws of European states have specifically targeted online grooming and criminalizing of such behaviour.

It is especially the legislation of the United Kingdom that attracts attention. In the United Kingdom had been a number of worrying cases where adult men have met young children after contacting them initially by e-mail or through internet chat-rooms. ${ }^{22}$ The United Kingdom was one of the first European states which initiated strong legislation that makes it illegal to contact and groom children with the intent of committing a sexual offence. Today, the concept of grooming is recognized in the United Kingdom as a criminal offence. Grooming was made a criminal offence in $2003 .^{23}$

Several countries followed the United Kingdom lead in legislating against online grooming behaviour, for example Norway, the Netherlands. Norway is the other European state which in 2007 adopted the grooming legislation. ${ }^{24}$ In

19 KOOL, R.: Prevention by All Means? : A Legal Comparison of the Criminalization of Online Grooming and its Enforcement. In: Utrecht Law Review, Vol. 7 (2011), Issue 3 (pp. 46-69), p. 50.

20 CHOO, K.-K. R.: Online child grooming : A literature review on the misuse of social networking sites for grooming children for sexual offences. Canberra : Australian Institute of Criminology, 2009, p. 40.

21 DAVIDSON, J. - GROVE-HILLS, J. - BIFULCO, A. - GOTTSCHALK, P. - CARETTI, V. - PHAM, T. et WEBSTER, S.: Online Abuse : Literature Review and Policy Context. Review prepared for the European Commission Safer Internet Plus : European Online Grooming Project, 2011, p. 8.

22 BAINBRIDGE, D. I.: Introduction to Information Technology Law. $6^{\text {th }}$ edition. Essex : Pearson Education, 2007, p. 475.

23 See section 15 of the Sexual Offences Act 2003.

24 See section 201a of the Norwegian Criminal Code (General Civil Penal Code). 
the Netherlands, grooming was criminalized in $2010 .{ }^{25}$ In addition to that, the online grooming has been recognised as offence also outside the EU, for example in the USA, Australia, New Zealand. ${ }^{26}$

On the other hand, in states where is no law dealing specifically with online grooming, authorities must fall back on laws regarding various sexual offences. For example, in Belgium there is presently no law dealing specifically with online grooming. Consequently, prosecutors must fall back on laws regarding offences against public morality, incitement to debauchery, public indecency, and rape. Further, in Italy there is at present no law dealing specifically with online grooming Prosecutors must utilise laws regarding paedophilia and distribution of indecent images. ${ }^{27}$

\section{The Offence of Solicitation of Children for Sexual Purposes: Response of the EU in the light of the Directive 2011/92/EU}

\subsection{Necessity of Criminalizing the Solicitation of Children for Sexual Pur- poses}

The EU explicitly recognised protection of children's rights in the Charter of Fundamental Rights of the EU. ${ }^{28}$ As pointed out by the European Commission, sexual abuse and sexual exploitation of children are particularly serious forms of crime as they are directed against children, who have the right to special protection and care. They produce long-term physical, psychological and social harm to victims and its persistence undermines the core values of a modern society relating to the special protection of children. ${ }^{29}$ Moreover, the European Commission set itself the objective of maximising the use of its existing policies and instruments partly with a view to protecting children from violence and sexual exploitation inside and outside the EU. ${ }^{30}$

As far as sexual abuse of children is concerned, as the flagship legislation was the Council Framework Decision 2004/68/JHA on combating the sexual exploi-

25 See Article 248e of the Dutch Criminal Code (Wetboek van Strafrecht).

26 See CHOO, K.-K. R.: Online child grooming : A literature review on the misuse of social networking sites for grooming children for sexual offences. Canberra : Australian Institute of Criminology, 2009.

27 DAVIDSON, J. - GROVE-HILLS, J. - BIFULCO, A. - GOTTSCHALK, P. - CARETTI, V. - PHAM, T. et WEBSTER, S.: Online Abuse : Literature Review and Policy Context. Review prepared for the European Commission Safer Internet Plus : European Online Grooming Project, 2011, p. 18.

28 OJ, C 83/389 of 30.3.2010. See Article 24 of the Charter - The rights of the child.

29 Proposal for a Directive of the European Parliament and of the Council on combating the sexual abuse, sexual exploitation of children and child pornography, repealing Framework Decision 2004/68/JHA. COM(2010)94 final, p. 2.

30 See Communication form the European Commission - Towards an EU strategy on the rights of the child. $\operatorname{COM}(2006) 367$. 
tation of children and child pornography ${ }^{31}$ (hereinafter 'Framework Decision'). At EU level, the Framework Decision introduced a minimum of approximation of the EU Member States' legislation to criminalise the most serious forms of child sexual abuse and exploitation, to extend domestic jurisdiction, and to provide for a minimum of assistance to victims. Although the requirements have generally been put into implementation, the Framework Decision has a number of shortcomings. It approximated legislation only on a limited number of offences, it did not address new forms of abuse and exploitation using information technology, did not remove obstacles to prosecuting offences outside national territory, did not meet all the specific needs of child victims, and did not contain adequate measures to prevent offences. ${ }^{32}$

In spite the fact that online grooming is threat at the international level, taking into consideration the principle of nullum crimen sine lege, in most cases it is not possible enforce criminal liability. It is clear that grooming must inevitably be made a criminal offence in the whole Europe, respectively in all Member States of the EU. Since the ratification of the Treaty of Lisbon ${ }^{33}$ in 2009, EU legislators have enjoyed greater power to adopt legislation on criminal enforcement and sanctions, which has fed into policy making to combat child pornography on the Internet in particular and is now turning its attention to specific legislation focused on grooming. ${ }^{34}$

In March 2010 the European Commission introduced a Proposal for a 'new' Directive on combating sexual abuse, sexual exploitation of children and child pornography ${ }^{35}$ (hereinafter 'Proposal'). The Proposal introduced new criminal offences in the information technology environment, inter alia, including also online grooming. As pointed out by Kendall and Funk prior adopting the final version of the Directive, the directive's uncharacteristically aggressive 'U.S.-style' call for action - including the imposition of minimum terms of imprisonment, the criminalisation of grooming-related offences, and the enactment of extraterritorial provisions - was explicitly premised..$^{36}$

31 Council Framework Decision 2004/68/JHA of 22 December 2003 on combating the sexual exploitation of children and child pornography. OJ, L 13/44 of 20.1.2004.

32 Proposal for a Directive of the European Parliament and of the Council on combating the sexual abuse, sexual exploitation of children and child pornography, repealing Framework Decision 2004/68/JHA. COM(2010)94 final, p. 3.

33 Treaty of Lisbon amending the Treaty Establishing the EU and the Treaty Establishing the European Community. OJ C 306/231 of 13.12.2006.

34 DAVIDSON, J. - GROVE-HILLS, J. - BIFULCO, A. - GOTTSCHALK, P. - CARETTI, V. - PHAM, T. et WEBSTER, S.: Online Abuse: Literature Review and Policy Context. Review prepared for the European Commission Safer Internet Plus : European Online Grooming Project, 2011, p. 16.

35 Proposal for a Directive of the European Parliament and of the Council on combating the sexual abuse, sexual exploitation of children and child pornography, repealing Framework Decision 2004/68/JHA. COM(2010)94 final.

36 KENDALL, V. M. et FUNK, T. M.: Child Exploitation and Trafficking: Examining the Glob- 
In December 2011 was adopted the Directive 2011/92/EU on combating the sexual abuse and sexual exploitation of children and child pornography ${ }^{37}$ (hereinafter 'Directive'). Framework Decision is hereby replaced. ${ }^{38}$

\subsection{Directive 2011/92/EU: Scope of Application}

The Directive establishes minimum rules concerning the definition of criminal offences and sanctions in the area of sexual abuse and sexual exploitation of children, child pornography and solicitation of children for sexual purposes. It also introduces provisions to strengthen the prevention of those crimes and the protection of the victims thereof. ${ }^{39}$

The Directive is addressed to the EU Member States. They shall bring into force the laws, regulations and administrative provisions necessary to comply with the Directive by 18 December $2013 .{ }^{40}$ However, Denmark is not taking part in the adoption of the Directive and is not bound by it or subject to its application. $^{41}$

The directive introduces a list of conducts, what Member States of the EU shall take the necessary measures to ensure that they are punishable. It contains four groups of offences, namely:

- $\quad$ offences concerning sexual abuse (Article 3),

- offences concerning sexual exploitation (Article 4),

- $\quad$ offences concerning child pornography (Article 5), and

- $\quad$ solicitation of children for sexual purposes (Article 6).

\subsection{Solicitation of Children for Sexual Purposes}

Solicitation of children for sexual purposes is a threat with specific characteristics in the context of the Internet, as the latter provides unprecedented anonymity to users because they are able to conceal their real identity and personal characteristics, such as their age. Member States are encouraged to criminalise the conduct where the solicitation of a child to meet the offender for sexual purposes takes place in the presence or proximity of the child, for instance in the

al Challenges and U.S. Responses. Plymouth : Rowman \& Littlefield, 2011, p. 141.

37 Directive 2011/92/EU of the European Parliament and of the Council of 13 December 2011 on combating the sexual abuse and sexual exploitation of children and child pornography, and replacing Council Framework Decision 2004/68/JHA. OJ, L 335/1 of 17.12.2011.

38 Article 26 of the Directive.

39 Article 1 of the Directive.

40 Article 27(1) of the Directive.

41 In accordance with Articles 1 and 2 of the Protocol (No 22) on the position of Denmark annexed to the Treaty on EU and to the Treaty on the Functioning of the EU. OJ, C 83/299 of 30.3.2010. 
form of a particular preparatory offence, attempt to commit the offences referred to in this Directive or as a particular form of sexual abuse. ${ }^{42}$

As we have seen the Directive introduces at EU level new offence - solicitation of children for sexual purposes (Article 6 of the Directive). Under the Directive, the Member States shall take the necessary measures to ensure that intentional solicitation of children for sexual purposes is punishable.

Member States shall take the necessary measures to ensure that punishable is the proposal, by means of information and communication technology, by an adult to meet a child who has not reached the age of sexual consent, for the purpose of engaging in sexual activities with a child, or/and production of child pornography, where that proposal was followed by material acts leading to such a meeting. ${ }^{43}$ Moreover, Member States shall take the necessary measures to ensure that is punishable an attempt, by means of information and communication technology, to commit acquisition or possession of child pornography, or/ and knowingly obtaining access (by means of information) by an adult soliciting a child who has not reached the age of sexual consent to provide child pornography depicting that child. ${ }^{44}$ In addition to that, Member States shall take the necessary measures to ensure that inciting or aiding and abetting to commit any of the offences is punishable.

For purposes of the Directive, the term 'child' shall mean any person below the age of 18 years and 'age of sexual consent' shall mean the age below which, in accordance with national law of the EU Member State(s), it is prohibited to engage in sexual activities with a child. ${ }^{45}$ Child victims of any of the offences referred to in the Directive shall be considered as particularly vulnerable victims pursuant to the Council Framework Decision 2001/220/JHA on the standing of victims in criminal proceedings. ${ }^{46}$

As far as the term 'child pornography' is concerned, for purposes of the Directive it shall mean: ${ }^{47}$

- $\quad$ any material that visually depicts a child engaged in real or simulated sexually explicit conduct,

- any depiction of the sexual organs of a child for primarily sexual purposes,

- $\quad$ any material that visually depicts any person appearing to be a child engaged in real or simulated sexually explicit conduct or any depiction

42 Recital 19 of preamble the Directive.

43 Article 6(1) of the Directive.

44 Article 6(2) of the Directive.

45 Article 2(a)(b) of the Directive.

46 Council Framework Decision 2001/220/JHA of 15 March 2001 on the standing of victims in criminal proceedings. OJ, L 82/1 of 22.3.2001. See Articles 2(2), 8(4) and 14(1) of this Framework Decision.

47 Article 2(c) of the Directive. 
of the sexual organs of any person appearing to be a child, for primarily sexual purposes, or

- realistic images of a child engaged in sexually explicit conduct or realistic images of the sexual organs of a child, for primarily sexual purposes.

In addition to that, it should be noted that Member States shall take the necessary measures to establish their jurisdiction over the offences referred to in the Directive where the offence is committed in whole or in part within their territory, or where the offender is one of their nationals. ${ }^{48}$

\section{Conclusion}

Grooming is a well-known strategy used by many paedophiles. It is a subtle, painstaking and yet powerfully seductive process, which can take many days, months, or sometimes years, to evolve and prepare the child for sexual abuse. It can allow paedophiles to sexually abuse large numbers of children but remain undetected.

Rapid growth of the Internet and advances in technology mean enormous benefits to society. However, it is necessary to recognise that with the spread of the Internet comes the growth in the possibility of the system being abused by sex offenders. The Internet has introduced us to many new terms and phenomena. One which has received considerable attention is that of online grooming.

In spite the fact that online grooming is threat at the international level, taking into consideration the principle of nullum crimen sine lege, in most cases it is not possible enforce criminal liability. It is clear that grooming must inevitably be made a criminal offence in the whole Europe, respectively in all Member States of the EU.

In December 2011 was adopted the Directive 2011/92/EU on combating the sexual abuse and sexual exploitation of children and child pornography. It establishes minimum rules concerning the definition of criminal offences and sanctions in the area of sexual abuse and sexual exploitation of children, child pornography and solicitation of children for sexual purposes. It also introduces provisions to strengthen the prevention of those crimes and the protection of the victims thereof.

The Directive introduces at EU level new offence - solicitation of children for sexual purposes. Member States of the EU shall take the necessary measures to ensure that intentional solicitation of children for sexual purposes is punishable. They shall take the necessary measures to ensure that punishable is the proposal, by means of information and communication technology, by an adult to meet a child who has not reached the age of sexual consent, for the purpose of engaging in sexual activities with a child, or/and production of child pornography, where

48 Article 17 of the Directive.

(c) Palacký University Olomouc, Czech Republic, 2012. ISSN 1213-8770 (print), ISSN: 2464-6601 (online). 
ICLR, 2012, Vol. 12, No. 1.

that proposal was followed by material acts leading to such a meeting. Moreover, Member States shall take the necessary measures to ensure that is punishable an attempt, by means of information and communication technology, to commit acquisition or possession of child pornography, or/and knowingly obtaining access (by means of information) by an adult soliciting a child who has not reached the age of sexual consent to provide child pornography depicting that child. In addition to that, Member States shall take the necessary measures to ensure that inciting or aiding and abetting to commit any of the offences is punishable.

The Member States shall bring into force the laws, regulations and administrative provisions necessary to comply with the Directive by 18 December 2013. However, Denmark is not taking part in the adoption of the Directive and is not bound by it or subject to its application. 